\section{The Influence of Day and Night Temperature Fluctuations on Growth and Flowering of Annual Bedding Plants and Greenhouse Heating Cost Predictions}

\author{
Matthew G. Blanchard ${ }^{1,3}$ and Erik S. Runkle ${ }^{2}$ \\ Department of Horticulture, Michigan State University, A288 PSSB, East \\ Lansing, MI 48824
}

Additional index words. Dahlia $\times$ hybrida, DIF, mean daily temperature, stem elongation, Tagetes patula, thermomorphogenesis, Zinnia elegans

\begin{abstract}
Volatile energy costs and lower profit margins have motivated many greenhouse growers in temperate climates to improve the energy efficiency of crop production. We performed experiments with dahlia (Dahlia $\times$ hybrida Cav. 'Figaro Mix'), French marigold (Tagetes patula L. 'Janie Flame'), and zinnia (Zinnia elegans Jacq. 'Magellan Pink') to quantify the effects of constant and fluctuating temperatures on growth and flowering during the finish stage. Plants were grown in glass-glazed greenhouses with a day/night $(16 \mathrm{~h} / 8 \mathrm{~h})$ temperature of $20 / 14,18 / 18,16 / 22$ (means of $\left.18{ }^{\circ} \mathrm{C}\right), 24 / 18,22 / 22$, or $20 / 26^{\circ} \mathrm{C}$ (means of $22^{\circ} \mathrm{C}$ ) with a 16 -h photoperiod and under a photosynthetic daily light integral of 11 to $19 \mathrm{~mol} \cdot \mathrm{m}^{-2} \cdot \mathrm{d}^{-1}$. Flowering times of dahlia, French marigold, and zinnia (Year 2 only) were similar among treatments with the same mean daily air temperature (MDT). All species grown at $20 / 14{ }^{\circ} \mathrm{C}$ were $10 \%$ to $41 \%$ taller than those grown at 16 / $22{ }^{\circ} \mathrm{C}$. Crop timing data and computer software that estimates energy consumption for heating (Virtual Grower) were then used to estimate energy consumption for greenhouse heating on a per-crop basis. Energy costs to produce these crops in Charlotte, NC, Grand Rapids, MI, and Minneapolis, MN, for a finish date of $15 \mathrm{Apr}$. or 15 May and grown at the same MDT were estimated to be $3 \%$ to $42 \%$ lower at a $+6{ }^{\circ} \mathrm{C}$ day/night temperature difference (DIF) compared with a $0{ }^{\circ} \mathrm{C}$ DIF and $2 \%$ to $90 \%$ higher at a $-6{ }^{\circ} \mathrm{C}$ DIF versus a $0{ }^{\circ} \mathrm{C}$ DIF. This information could be used by greenhouse growers to reduce energy inputs for heating on a per-crop basis.
\end{abstract}

In many plant species, stem elongation is influenced by the difference between the DIF (Myster and Moe, 1995). Stem elongation is promoted when the day temperature is higher than the night temperature (+DIF) and suppressed when the day temperature is lower than the night temperature (-DIF). The effect of DIF on plant height has been studied in many common greenhouse crops such as

Received for publication 24 Nov. 2010. Accepted for publication $9 \mathrm{Feb} .2011$

We gratefully acknowledge funding by Michigan's plant agriculture initiative at Michigan State University (Project GREEEN), the Michigan Agricultural Experiment Station, the American Floral Endowment, the Fred C. Gloeckner Foundation, the USDA-ARS Floriculture and Nursery Research Initiative, and greenhouse growers providing support for Michigan State University floriculture research. We also thank Jonathan Franz for his contributions to this manuscript, C. Raker \& Sons for donation of plant material, and Mike Olrich for his greenhouse assistance.

${ }^{1}$ Former Graduate Research Associate. Current address: Syngenta Flowers, 2280 Hecker Pass Highway, Gilroy, CA 95020.

${ }^{2}$ Associate Professor and Extension Specialist.

${ }^{3}$ To whom reprint requests should be addressed; e-mailmgblanch@msu.edu.
Easter lily (Lilium longiflorum Thunb.; Erwin et al., 1989), pansy (Viola $\times$ wittrockiana Gams.; Niu et al., 2000), and poinsettia (Euphorbia pulcherrima Willd. ex Klotz; Berghage and Heins, 1991). For example, Erwin et al. (1989) reported that plant height of Easter lily increased by $129 \%$ as DIF increased from -16 to $+16{ }^{\circ} \mathrm{C}$. During the production of floriculture crops, a -DIF is sometimes used by greenhouse growers to control height (Myster and Moe, 1995).

In temperate climates, high-energy inputs can be required to maintain a desirable greenhouse temperature, making fuel for heating one of the largest floriculture production expenses (Bartok, 2001). Greenhouse growers can reduce energy consumption by managing the greenhouse environment with dynamic temperature control (DTC) strategies (Körner et al., 2007; Lund et al., 2006). In DTC, in contrast to static temperature control, heating set points are lowered during periods when the greenhouse energy loss factor is high (e.g., outside temperature and incoming solar radiation are low) and increased when the energy loss factor is low (Körner et al., 2004). This environmental control strategy integrates temperature and maintains a target MDT over a 1- to 7-d interval (Körner et al., 2004; Körner and Challa, 2003). Lund et al.
(2006) reported that a greenhouse in Denmark using DTC had $32 \%$ to $79 \%$ and $75 \%$ to $89 \%$ lower energy consumption for heating during winter and spring months, respectively, compared with a greenhouse using static temperature set points.

To achieve the greatest potential energy savings with temperature integration, a greenhouse environmental control computer with sophisticated software (e.g., DTC) is required (Aaslyng et al., 2005). However, not all greenhouses use environmental control computers, and of those that do, relatively few use DTC strategies. An alternative and simple energy-saving approach is to use a +DIF with static day and night heating and ventilation set points. With a + DIF, the heating set point is lowered during the night when energy consumption for heating is highest (Bartok, 2001). A low night temperature is compensated for by increasing the day temperature so that the target MDT is achieved.

A DTC or DIF strategy to reduce energy consumption assumes that plant developmental rate is controlled by the integrated MDT (Summerfield et al., 1991) and crop time is similar at different day and night temperatures (within limits) that deliver the same MDT. However, studies with bedding plants that compared flowering times at DIF and constant temperatures regimens with the same MDT have reported different responses among species. For example, geranium ( $\mathrm{Pel}$ argonium $\times$ hortorum Bailey) grown at an MDT of $18{ }^{\circ} \mathrm{C}$ flowered similarly at day/ night $(12 \mathrm{~h} / 12 \mathrm{~h})$ set points of $18 / 18$ or $27 /$ $9{ }^{\circ} \mathrm{C}$ (White and Warrington, 1988). In contrast, Mortensen and Moe (1992) reported that petunia 'Ultra Red' (Petunia $\times$ hybrida Vilm.-Andr.) flowered $5 \mathrm{~d}$ earlier at a day/ night $(16 \mathrm{~h} / 8 \mathrm{~h})$ of $21 / 15{ }^{\circ} \mathrm{C}$ compared with $19 / 19$ and $17 / 23{ }^{\circ} \mathrm{C}$, whereas red salvia (Salvia splendens F. Sello ex Roem \& Schult.) flowered $5 \mathrm{~d}$ later at $17 / 23{ }^{\circ} \mathrm{C}$ compared with $19 / 19$ and $21 / 15^{\circ} \mathrm{C}$. Therefore, the benefits of using DIF to reduce energy inputs or to suppress stem elongation may not be practical for all bedding plant species if crop time is delayed. The objectives of this research were to 1) quantify the effects of constant and fluctuating temperatures on growth and flowering during the finish stage of three bedding plant species; and 2) predict greenhouse heating costs for different crop finish dates, at different locations in the United States, with different DIF regimens.

\section{Materials and Methods}

During Sept. 2008 (Year 1) and Mar. 2009 (Year 2), seeds of dahlia (Dahlia $\times$ hybrida Cav. 'Figaro Mix'), French marigold (Tagetes patula L. 'Janie Flame'), and zinnia (Zinnia elegans Jacq. 'Magellan Pink') were sown in plug trays [288-cell size (6-mL volume)] by a commercial greenhouse (C. Raker \& Sons, Litchfield, MI). In Year 1, zinnia received a foliar spray of paclobutrazol (Bonzi; Syngenta Crop Protection, Inc., Greensboro, NC) within $10 \mathrm{~d}$ of seed sow, at an unreported rate and volume, to suppress hypocotyl elongation. 
Ten to $17 \mathrm{~d}$ after seed sowing, plugs were received at Michigan State University (MSU) and were grown in a controlled environmental growth chamber at a constant temperature set point of $20^{\circ} \mathrm{C}$. A 16-h photoperiod was provided by $215-\mathrm{W}$ cool-white fluorescent (CWF; F96T12CWVHO; Philips, Somerset, NJ) and 60-W incandescent lamps (INC; Philips) at a CWF:INC (by wattage) of 3.6 and at an intensity of 160 to $180 \mu \mathrm{mol} \cdot \mathrm{m}^{-2} \cdot \mathrm{s}^{-1}$ at plant height. Plants were irrigated as necessary with well water acidified with $\mathrm{H}_{2} \mathrm{SO}_{4}$ to a titratable alkalinity of $140 \mathrm{mg} \cdot \mathrm{L}^{-1}$ $\mathrm{CaCO}_{3}$ and containing 95, 34, and $29 \mathrm{mg} \cdot \mathrm{L}^{-1}$ calcium, magnesium, and sulfur, respectively. The water was supplemented with a watersoluble fertilizer providing $\left(\mathrm{mg} \cdot \mathrm{L}^{-1}\right) 62$ nitrogen $(\mathrm{N}), 6$ phosphorus $(\mathrm{P}), 62$ potassium $(\mathrm{K}), 7$ calcium $(\mathrm{Ca}), 0.5$ iron $(\mathrm{Fe}), 0.3$ copper $(\mathrm{Cu}), 0.3$ manganese $(\mathrm{Mn}), 0.3$ zinc $(\mathrm{Zn}), 0.1$ boron (B), and 0.1 molybdenum (Mo) (MSU Well Water Special; GreenCare Fertilizers, Inc., Kankakee, IL).

Greenhouse environment. After $26 \mathrm{~d}$ (dahlia), 19 or $23 \mathrm{~d}$ (French marigold), and 23 or $16 \mathrm{~d}$ (zinnia) from seed sowing, seedlings were thinned to one seedling per cell and transplanted into $10-\mathrm{cm}$ round plastic containers (480-mL volume) filled with a commercial soilless peat-based medium (Suremix; Michigan Grower Products, Inc., Galesburg, MI). At transplant, dahlia, French marigold, and zinnia had a mean of three, six, or six leaves, respectively. Fifteen plants of each species were randomly assigned to each of six glassglazed greenhouse sections with constant day/night $(16 \mathrm{~h} / 8 \mathrm{~h})$ temperature set points of $18 / 18$ or $22 / 22{ }^{\circ} \mathrm{C}$ or fluctuating day/ night $(16 \mathrm{~h} / 8 \mathrm{~h})$ temperature set points of $20 / 14,16 / 22,24 / 18$, or $20 / 26{ }^{\circ} \mathrm{C}$. The temperature set points were chosen so that three treatments each had an MDT of 18 or $22{ }^{\circ} \mathrm{C}$. In each greenhouse section, temperature set points were maintained by an environmental computer (Priva Intégro 724; Priva, Vineland Station, Ontario, Canada) that controlled steam heating, passive and active ventilation, and evaporative cooling pads when needed. The transition period between the day and night temperature set points was $3 \mathrm{~min} /{ }^{\circ} \mathrm{C}$. The experiment was performed twice with transplant dates beginning on 18 Oct. 2008 (Year 1) and 20 Mar. 2009 (Year 2).

The photoperiod was maintained at $16 \mathrm{~h}$ and consisted of natural photoperiods (lat. $43^{\circ} \mathrm{N}$ ) with day-extension lighting from 0600 to 2200 HR provided by high-pressure sodium (HPS) lamps. The HPS lamps were operated by an environmental computer and were turned on when the outside light intensity was less than $290 \mu \mathrm{mol} \cdot \mathrm{m}^{-2} \cdot \mathrm{s}^{-1}$ and turned off at greater than $580 \mu \mathrm{mol} \cdot \mathrm{m}^{-2} \cdot \mathrm{s}^{-1}$. The photoperiod and skotoperiod paralleled the day and night temperature set points, respectively. In Year 2, whitewash was applied to the greenhouse glazing so that the maximum photosynthetic photon flux $(P P F)$ was $1200 \mu \mathrm{mol} \cdot \mathrm{m}^{-2} \cdot \mathrm{s}^{-1}$ at plant height. A maximum vapor pressure deficit of $1.2 \mathrm{kPa}$ was maintained during the night by the injection of steam into the air. Horizontal airflow fans positioned $1.4 \mathrm{~m}$ above the growing surface operated if the ridge vent was less than $90 \%$ of the maximum opening and provided air movement at $\approx 0.1 \mathrm{~m} \cdot \mathrm{s}^{-1}$ at plant height [as measured with an air velocity transducer (8475; TSI, Inc., St. Paul, MN)].

Environmental monitoring and plant culture. Air temperature was independently measured in each greenhouse by an aspirated, shielded thermocouple $(0.13-\mathrm{mm}$ type E; Omega Engineering, Stamford, CT) positioned at plant level. In each temperature treatment, the $P P F$ was measured by a line quantum sensor containing 10 photodiodes (Apogee Instruments, Inc., Logan, UT) positioned at $30 \mathrm{~cm}$ above the bench. Environmental measurements were collected every $10 \mathrm{~s}$ and hourly means were recorded by a data logger (CR10; Campbell Scientific, Logan, UT). Temperature control during the experiment was within $1.3^{\circ} \mathrm{C}$ of the greenhouse temperature set points for all treatments in both years and the actual MDT was $18.0 \pm$ $0.4{ }^{\circ} \mathrm{C}$ or $22.0 \pm 0.2{ }^{\circ} \mathrm{C}$ (Figs. 1 and 2). The mean photosynthetic daily light integral (DLI) from transplant to flowering ranged from 10.6 to $12.3 \mathrm{~mol} \cdot \mathrm{m}^{-2} \cdot \mathrm{d}^{-1}$ in Year 1 and 15.7 to $19.1 \mathrm{~mol} \cdot \mathrm{m}^{-2} \cdot \mathrm{d}^{-1}$ in Year 2 (Table 1 ).

Plants were irrigated as necessary with reverse osmosis water supplemented with a water-soluble fertilizer providing $\left(\mathrm{mg} \cdot \mathrm{L}^{-1}\right)$ $125 \mathrm{~N}, 12 \mathrm{P}, 100 \mathrm{~K}, 65 \mathrm{Ca}, 12 \mathrm{Mg}, 1.0 \mathrm{Fe}, 1.0$ $\mathrm{Cu}, 0.5 \mathrm{Mn}, 0.5 \mathrm{Zn}, 0.3 \mathrm{~B}$, and 0.1 Mo (MSU RO Water Special; GreenCare Fertilizers, Inc.).

Data collection and analysis. The date of first open inflorescence (flowering) was recorded and time to flower was calculated for each plant. Plants were considered flowering when each species had an inflorescence with at least $50 \%$ of the ray petals fully reflexed. When each plant flowered, plant height and the number of inflorescences were recorded. Plant height was measured from the soil surface to the base of the first whorl of flowers on an inflorescence. Data were

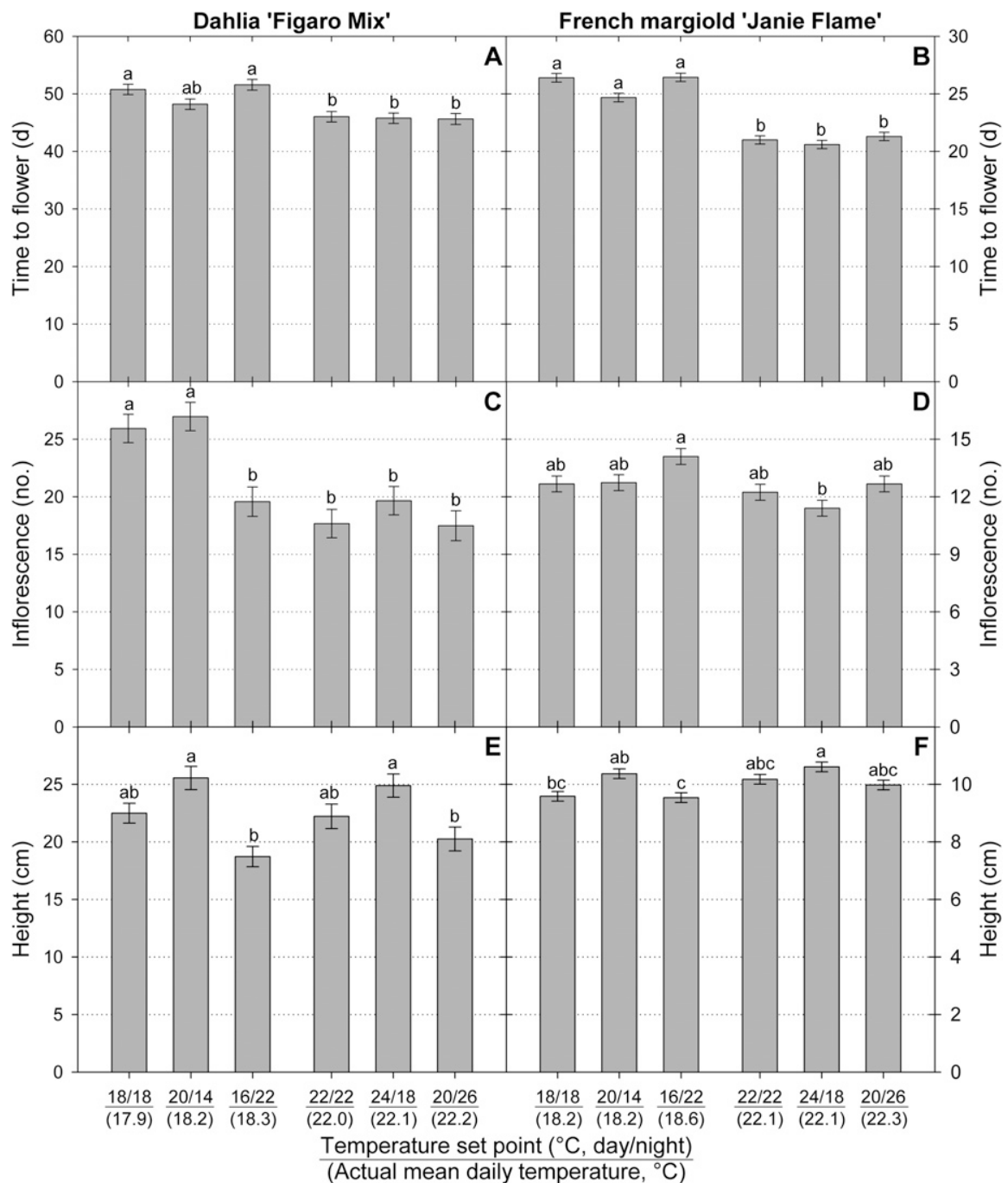

Fig. 1. The influence of temperature on time to flower $(\mathbf{A}-\mathbf{B})$, inflorescence number $(\mathbf{C}-\mathbf{D})$, and height $(\mathbf{E}-$ F) at flowering, in dahlia 'Figaro Mix' and French marigold 'Janie Flame' at constant and fluctuating day/night $(16 \mathrm{~h} / 8 \mathrm{~h})$ temperature set points. Vertical bars indicate sES of treatment means. Mean separation by Tukey's honestly significant difference test at $P \leq 0.01$. For both species, data were pooled between replications. 


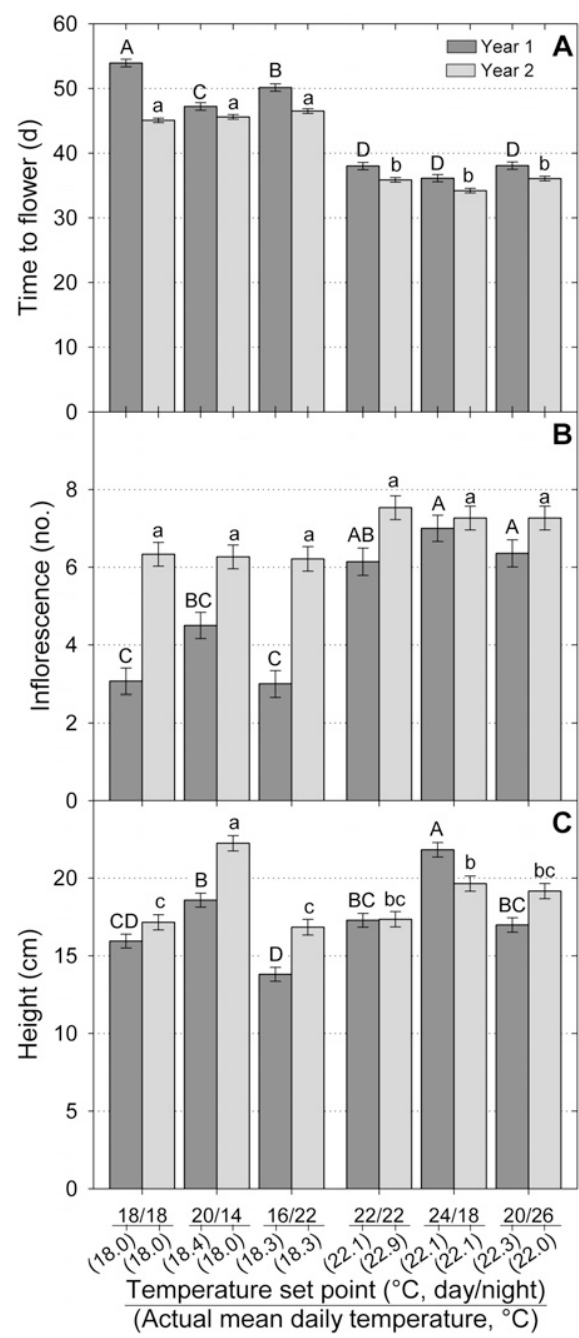

Fig. 2. The influence of temperature on time to flower (A), inflorescence number (B), and height (C) at flowering, in zinnia 'Magellan Pink' at constant and fluctuating day/night $(16 \mathrm{~h} / 8 \mathrm{~h})$ temperature set points. Vertical bars indicate SES of treatment means. Mean separation by Tukey's honestly significant difference test at $P \leq 0.01$. Data were analyzed separately for each year.

Table 1. Mean daily light integral in temperature treatments during experiments in Years 1 and 2.

\begin{tabular}{llr}
\hline $\begin{array}{l}\text { Day/night } \\
\text { temp set } \\
\text { point }\left({ }^{\circ} \mathrm{C}\right)\end{array}$ & \multicolumn{2}{c}{$\begin{array}{c}\text { Daily light integral } \\
\left(\mathrm{mol} \cdot \mathrm{m}^{-2} \cdot \mathrm{d}^{-1}\right)\end{array}$} \\
\cline { 2 - 3 } $18 / 18$ & $\mathrm{Yr} \mathrm{1}$ & $\mathrm{Yr} \mathrm{2}$ \\
$20 / 14$ & 11.6 & 15.9 \\
$16 / 22$ & 11.0 & 16.3 \\
$22 / 22$ & 11.0 & 16.9 \\
$24 / 18$ & 10.7 & 19.1 \\
$20 / 26$ & 12.3 & 15.7 \\
\hline
\end{tabular}

analyzed with the SAS (SAS Institute, Inc., Cary, NC) mixed model procedure (PROC MIXED), and pairwise comparisons between treatments were performed with Tukey's honestly significant difference test at $P \leq 0.01$. Data were pooled between replications because the treatment $\times$ year interaction was not significant at $P \leq 0.01$. Zinnia data were analyzed separately for each year because a plant growth retardant was applied to seedlings during Year 1.

Heating cost estimation. The cost to heat a $1991-\mathrm{m}^{2}$ greenhouse to produce a flowering crop grown at day/night $(16 \mathrm{~h} / 8 \mathrm{~h})$ temperature set points of $18 / 18,20 / 14,16 / 22$, $22 / 22,24 / 18$, or $20 / 26^{\circ} \mathrm{C}$ for finish dates of 15 Mar., 15 Apr., or 15 May was estimated for Charlotte, NC, Grand Rapids, MI, and Minneapolis, MN, by using the Virtual Grower 2.51 software (Frantz et al., 2010). Production time for each species was calculated from the greenhouse experiments by using the mean time to flower at an MDT of 18 or $22{ }^{\circ} \mathrm{C}$. Flowering time for zinnia was calculated according to data from Year 2 only. The greenhouse characteristics used to estimate heating costs included eight spans each $34.1 \times$ 7.3-m, arched 3.7-m roof, 2.7-m gutter, polyethylene double-layer roof, polycarbonate biwall ends and sides, forced air unit heaters burning natural gas, $50 \%$ heater efficiency, no energy curtain, an air infiltration rate of $1.0 / \mathrm{h}$, and day temperature set points from 0600 to 2200 HR. These values and characteristics are typical of commercial greenhouses used to produce floriculture crops in the northern half of the United States. Cities were subjectively chosen from a list of the largest garden plant-producing states in the United States (U.S. Department of Agriculture, 2010) and were selected if they had an outside MDT less than $10{ }^{\circ} \mathrm{C}$ during January, February, March, and April (U.S. Department of Energy, 1995).

\section{Results}

Dahlia and French marigold plants grown at a similar MDT did not differ in time to flower (Fig. 1A-B). For example, French marigold flowered $26 \mathrm{~d}$ after transplant when grown at $18 / 18,20 / 14$, or $16 / 22^{\circ} \mathrm{C}$ and $21 \mathrm{~d}$ when grown at $22 / 22,24 / 18$, or $20 / 26{ }^{\circ} \mathrm{C}$. Zinnia plants grown at a similar MDT flowered at the same time in Year 2 but not Year 1 (Fig. 2A). In Year 1, zinnia grown at $20 / 14{ }^{\circ} \mathrm{C}$ flowered 3 to $7 \mathrm{~d}$ earlier than plants grown at $18 / 18$ or $16 / 22{ }^{\circ} \mathrm{C}$

Dahlia grown at $18 / 18$ or $20 / 14{ }^{\circ} \mathrm{C}$ had a mean of eight more inflorescences than plants grown at $22 / 22,24 / 18,20 / 26$, or 16 / $22{ }^{\circ} \mathrm{C}$ (Fig. 1C). French marigold had a similar inflorescence number among treatments, although those grown at $16 / 22^{\circ} \mathrm{C}$ had a mean of three more than those at $24 / 18{ }^{\circ} \mathrm{C}$ (Fig. 1D). In Year 1 , when the mean DLI was $\approx 11$ $\mathrm{mol} \cdot \mathrm{m}^{-2} \cdot \mathrm{d}^{-1}$, zinnia grown at an MDT of $22{ }^{\circ} \mathrm{C}$ developed two or three more inflorescences than plants grown at an MDT of $18^{\circ} \mathrm{C}$ (Fig. 2B). In contrast, inflorescence number was similar among temperature treatments in Year 2 , when the mean DLI was $\approx 17$ $\mathrm{mol} \cdot \mathrm{m}^{-2} \cdot \mathrm{d}^{-1}$.

Dahlia grown at a $+6{ }^{\circ} \mathrm{C}$ DIF $(20 / 14$ or $24 /$ $18{ }^{\circ} \mathrm{C}$ ) was 4.6 to $5.3 \mathrm{~cm}$ taller at flowering than plants grown at a $-6{ }^{\circ} \mathrm{C}$ DIF $(16 / 22$ or $20 / 26{ }^{\circ} \mathrm{C}$; Fig. 1E). In French marigold, plants were $11 \%$ taller when grown at $20 / 14$ or $24 / 18{ }^{\circ} \mathrm{C}$ versus $16 / 22{ }^{\circ} \mathrm{C}$ (Fig. 1F). In
Year 1 , zinnia grown at $24 / 18{ }^{\circ} \mathrm{C}$ were $17 \%$ to $58 \%$ taller than plants in all other treatments, whereas in Year 2, plants grown at $20 / 14{ }^{\circ} \mathrm{C}$ were $13 \%$ to $32 \%$ taller than plants in all other treatments (Fig. 2C). For all species, there were no differences in height between plants grown at a $0{ }^{\circ} \mathrm{C}$ DIF

In all species and locations, energy for heating predictions to produce a flowering crop for 15 Apr. or 15 May were up to $41 \%$ lower when grown at a $+6{ }^{\circ} \mathrm{C}$ DIF compared with a constant temperature (Table 2). As finish date progressed from 15 Mar. to 15 May, the relative difference in heating costs between $\mathrm{a}+6^{\circ} \mathrm{C}$ DIF and $0{ }^{\circ} \mathrm{C}$ DIF increased. Heating costs per crop for all locations and finish dates were estimated to be greatest when grown at $16 / 22,20 / 26$, or $22 / 22^{\circ} \mathrm{C}$. For example, dahlia grown in Minneapolis, $\mathrm{MN}$, would consume $2 \%$ to $29 \%$ more energy if grown at $16 / 22{ }^{\circ} \mathrm{C}$ versus $18 / 18$ or $20 / 14{ }^{\circ} \mathrm{C}$. In nearly all instances, the least amount of energy consumed per crop of dahlia or French marigold occurred at $20 / 14{ }^{\circ} \mathrm{C}$. In contrast, the lowest energy input for a crop of zinnia was $24 / 18{ }^{\circ} \mathrm{C}$ for a 15 Mar. finish date and $\mathrm{a}+6^{\circ} \mathrm{C}$ DIF for the later two finish dates. The estimated energy consumption for heating was greatest for dahlia grown at $20 / 26^{\circ} \mathrm{C}$ or constant $22^{\circ} \mathrm{C}$ regardless of location or finish date. For French marigold and zinnia, greenhouse heating was greatest for a crop grown at a $-6{ }^{\circ} \mathrm{C}$ DIF. As finish date increased from 15 Mar. to 15 May, heating costs at each temperature regimen decreased by $52 \%$ to $84 \%$. For example, zinnia grown for 15 May at $20 / 14{ }^{\circ} \mathrm{C}$ would require $77 \%$ less energy input for heating than the same crop grown for 15 Mar.

\section{Discussion}

Flowering time of dahlia, French marigold, and zinnia (Year 2 only) was similar among temperature treatments with the same MDT. This response reinforces the paradigm that flowering rate is a function of the MDT and, within limits, the effects of day and night temperature on progress toward flowering are equal (Niu et al., 2000; Summerfield et al., 1991). Our results are in agreement with those of Mortensen and Moe (1992), who reported no difference in flowering time of fuchsia (Fuchsia $\times$ hybrida hort. ex Sieb. and Voss), geranium, impatiens (Impatiens walleriana Hook.f.), pocketbook plant (Calceolaria $\times$ herbeohybrida Voss), potted rose, and tuberous begonia (Begonia $\times$ tuberhybrida pendula) grown at day/night $(16 \mathrm{~h} / 8 \mathrm{~h})$ temperature set points of $19 / 19,21 / 15$, or $17 / 23{ }^{\circ} \mathrm{C}$. Similarly, flowering time was controlled by MDT and not DIF in pinnate dahlia (Dahlia pinnata Cav.; Brøndum and Heins, 1993), pansy (Niu et al., 2000), and vinca (Catharanthus roseus L.; Pietsch et al., 1995).

Crop models that predict flowering time under different environmental conditions have been developed for several bedding plants such as celosia (Celosia argentea L. var. plumosa Voss), impatiens, petunia, and 
Table 2. Predicted relative amount of energy used for greenhouse heating to produce three annual species grown at different day and night temperature set points in different locations and finish dates ${ }^{2}$

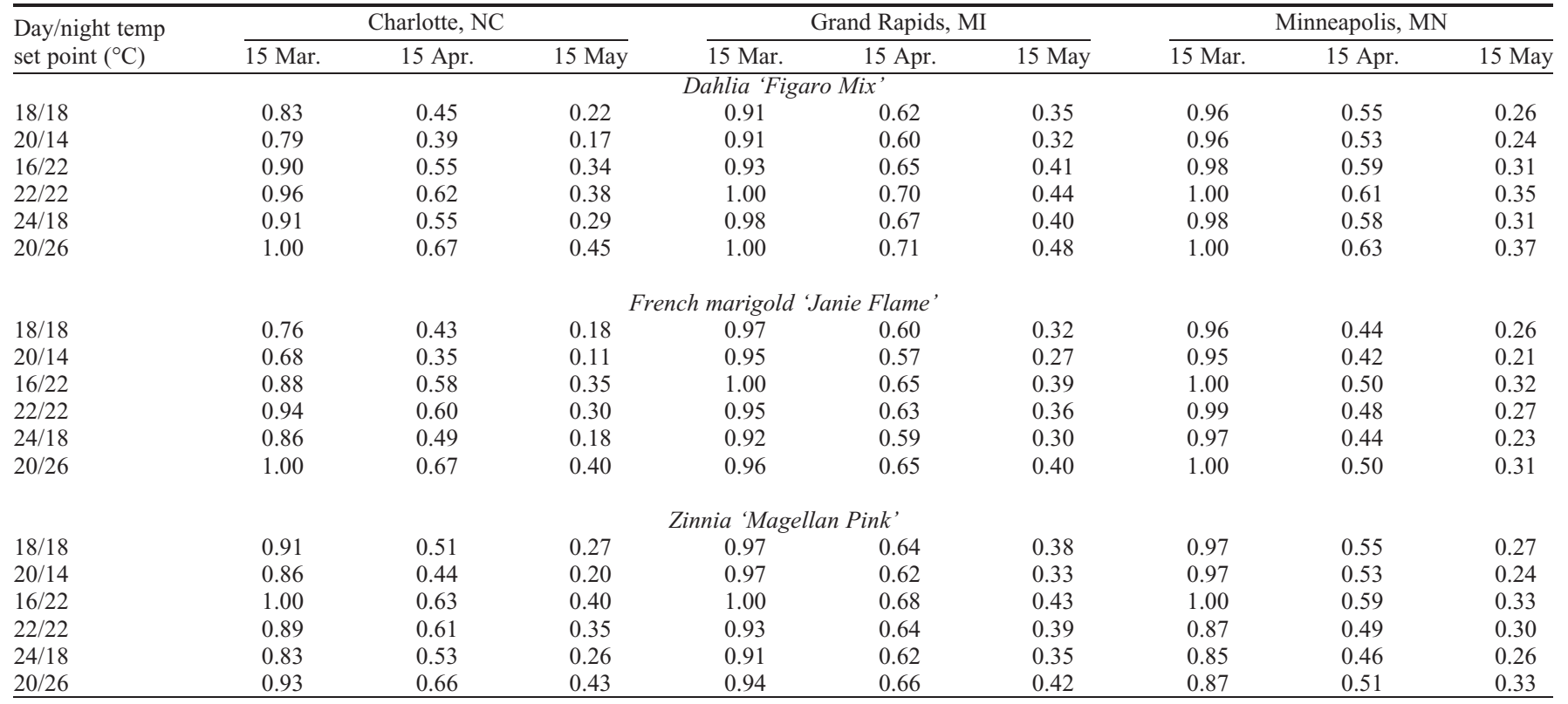

${ }^{2}$ Values were calculated by dividing heating input by the highest input for each location and species and thus are unitless. Heating inputs were estimated using Virtual Grower software (Frantz et al., 2010) and include time from transplant to first flowering on 15 Mar., 15 Apr., or 15 May. Production time for each species was calculated from greenhouse experiments using the mean time to flower at $18 / 18,20 / 14$, and $16 / 22{ }^{\circ} \mathrm{C}$ or $22 / 22,24 / 18$, and $20 / 26^{\circ} \mathrm{C}$. See "Materials and Methods" for greenhouse and heating parameter inputs.

pinnate dahlia (Adams et al., 1998; Brøndum and Heins, 1993; Pramuk and Runkle, 2005). In many of these experiments, models were generated with data from plants that were grown at constant temperature set points. For example, flowering models predicted that as constant temperature set points increased from 14 to $26{ }^{\circ} \mathrm{C}$, time to flower in celosia and impatiens grown under a DLI of 15 $\mathrm{mol} \cdot \mathrm{m}^{-2} \cdot \mathrm{d}^{-1}$ decreased by 38 and $15 \mathrm{~d}$, respectively (Pramuk and Runkle, 2005). Data from our study presenting similar flowering times at different day/night treatments with the same MDT indicate that these crop models could also be used to predict flowering time at fluctuating temperature set points. Caveats of many crop models that predict flowering time are that they are valid only if the day and night temperatures are greater than or equal to a species-specific base temperature and less than or equal to the optimum temperature (Summerfield et al., 1991).

In zinnia during Year 1, flowering time was different among treatments with an MDT of $18^{\circ} \mathrm{C}$. The actual MDT among these treatments varied by only 0.1 to $0.4{ }^{\circ} \mathrm{C}$ and plants received a DLI within $0.6 \mathrm{~mol} \cdot \mathrm{m}^{-2} \cdot \mathrm{d}^{-1}$. Therefore, it is not clear why plants grown at $20 / 14{ }^{\circ} \mathrm{C}$ flowered later than those grown at a constant 18 or $16 / 22^{\circ} \mathrm{C}$. Zinnia in Year 1 grown at an MDT of $18^{\circ} \mathrm{C}$ also had a mean of three less inflorescences compared with an MDT of $22{ }^{\circ} \mathrm{C}$. The flowering delay and reduced inflorescence number could be at least partially attributed to the paclobutrazol application during the plug stage, which has been shown to delay flowering in some crops (Blanchard and Runkle, 2007). These responses could also have been affected by the DLI that zinnia received. DLI can interact with MDT to influence flower developmental rate and plant quality (Pramuk and Runkle, 2005).

Plant height at flower in all species generally increased as DIF increased from -6 to $+6{ }^{\circ} \mathrm{C}$. These results are in agreement with Myster and Moe's (1995) findings that the relative promotion or suppression of stem elongation is influenced by the magnitude of DIF. Similar effects of DIF on plant height have been reported in other bedding plants, including geranium (Mortensen and Moe, 1992), pinnate dahlia (Brøndum and Heins, 1993), impatiens (Mortensen and Moe, 1992), pansy (Niu et al., 2000), petunia (Kaczperski et al., 1991), red salvia (Mortensen and Moe, 1992), snapdragon (Antirrhinum majus L.; Neily et al., 1997), and zinnia (Neily et al., 1997). For example, stem elongation during the vegetative stage in snapdragon and zinnia increased by $38 \%$ and $13 \%$, respectively as DIF (13-h day/11-h night) increased from -5 to $+5^{\circ} \mathrm{C}$ (Neily et al., 1997).

Although a + DIF temperature regimen promoted stem elongation, greenhouse energy inputs to heat these bedding plants at these locations and finish dates were estimated to be lowest with a +DIF. For example, the estimated energy inputs to produce these three crops in Charlotte, NC, Grand Rapids, MI, and Minneapolis, MN, for a finish date of 15 Mar. were similar or up to $11 \%$ lower if plants were grown at $+6{ }^{\circ} \mathrm{C}$ DIF instead of a constant temperature. In contrast, for a finish date of 15 May, energy inputs at the same MDT were estimated to be $9 \%$ to $42 \%$ lower at a $+6{ }^{\circ} \mathrm{C}$ DIF compared with a $0{ }^{\circ} \mathrm{C}$ DIF. Similar results were reported in a simulated greenhouse study in The Netherlands: total annual energy consumption was $9 \%, 13 \%$, and 23\% lower during February, March, and April, respectively, with a $+6{ }^{\circ} \mathrm{C}$ DIF compared with a $-2{ }^{\circ} \mathrm{C}$ DIF (Körner et al., 2004).

These results collectively indicate that for many locations, a + DIF temperature regimen is an energy-efficient production strategy for these species, and the energy savings with + DIF increases with later spring production dates. Because bedding plants grown at some + DIF treatments were taller than those grown at a constant or -DIF temperature regimen, the advantages and disadvantages of DIF should be considered. If a +DIF temperature regimen is used to save energy, growers may need to use an alternative height control strategy to suppress stem elongation. An example of a height control strategy could be the application of a chemical plant growth retardant (Blanchard and Runkle, 2007). Plants grown under a -DIF had suppressed stem elongation but were estimated to require the highest energy inputs to produce. An economic analysis could determine whether it is more costeffective to deliver a + DIF to save energy and use different height control strategies or to deliver a -DIF with more energy inputs but fewer height control requirements.

\section{Literature Cited}

Aaslyng, J.M., N. Ehler, and L. Jakobsen. 2005. Climate control software integration with a greenhouse environmental control computer. Environ. Model. Softw. 20:521-527.

Adams, S.R., P. Hadley, and S. Pearson. 1998. The effects of temperature, photoperiod, and photosynthetic photon flux on the time to flowering of Petunia ‘Express Blush Pink'. J. Amer. Soc. Hort. Sci. 123:577-580.

Bartok, J.W., Jr. 2001. Energy conservation for commercial greenhouses. Natural Resource, Agr., and Eng. Serv. Coop. Ext., Ithaca, NY. 
Berghage, R.D. and R.D. Heins. 1991. Quantification of temperature effects on stem elongation in poinsettia. J. Amer. Soc. Hort. Sci. 116:14 18.

Blanchard, M.G. and E.S. Runkle. 2007. Dipping bedding plant liners in paclobutrazol or uniconazole inhibits subsequent stem extension. HortTechnology 17:178-182.

Brøndum, J.J. and R.D. Heins. 1993. Modeling temperature and photoperiod effects on growth and development of dahlia. J. Amer. Soc. Hort. Sci. 118:36-42.

Erwin, J.E., R.D. Heins, and M.G. Karlsson. 1989. Thermomorphogenesis in Lilium longiflorum. Amer. J. Bot. 76:47-52.

Frantz, J.M., B. Hand, L. Buckingham, and S. Ghose. 2010. Virtual Grower: Software to calculate heating costs of greenhouse production in the United States. HortTechnology 20: 778-785.

Kaczperski, M.P., W.H. Carlson, and M.G. Karlsson. 1991. Growth and development of Petunia $\times$ hybrids as a function of temperature and irradiance. J. Amer. Soc. Hort. Sci. 116:232237.

Körner, O., J.M. Aaslyng, A.U. Andreassen, and N. Holst. 2007. Microclimate prediction for dynamic greenhouse climate control. HortScience 42:272-279.
Körner, O., M.J. Bakker, and E. Heuvelink. 2004. Daily temperature integration: A simulation study to quantify energy consumption. Biosystems Eng. 87:333-343.

Körner, O. and H. Challa. 2003. Temperature integration and DIF in cut chrysanthemum. J. Hortic. Sci. Biotechnol. 78:335-342.

Lund, J.B., A. Andreassen, C.-O. Ottosen, and J.M Aaslyng. 2006. Effect of a dynamic climate on energy consumption and production of Hibiscus rosa-sinensis L. in greenhouses. HortScience 41:384-388.

Mortensen, L.M. and R. Moe. 1992. Effects of various day and night temperature treatments on the morphogenesis and growth of some greenhouse and bedding plant species. Acta Hort. 327:77-86.

Myster, J. and R. Moe. 1995. Effect of diurnal temperature alternations on plant morphology in some greenhouse crops-A mini review. Sci. Hort. 62:205-215.

Neily, W.G., P.R. Hicklenton, and D.N. Kristie. 1997. Temperature and developmental stage influence diurnal rhythms of stem elongation in snapdragon and zinnia. J. Amer. Soc. Hort. Sci. 122:778-783.

Niu, G., R.D. Heins, A.C. Cameron, and W.H. Carlson. 2000. Day and night temperatures, daily light integral, and $\mathrm{CO}_{2}$ enrichment affect growth and flower development of pansy (Viola $\times$ wittrockiana). J. Amer. Soc. Hort. Sci. 125: 436-441.

Pietsch, G.M., W.H. Carlson, R.D. Heins, and J.E. Faust. 1995. The effect of day and night temperature and irradiance on development of Catharanthus roseus (L.) 'Grape Cooler'. J. Amer. Soc. Hort. Sci. 120:877-881.

Pramuk, L.A. and E.S. Runkle. 2005. Modeling growth and development of celosia and impatiens in response to temperature and photosynthetic daily light integral. J. Amer. Soc. Hort. Sci. 130:813-818.

Summerfield, R.J., E.H. Roberts, R.H. Ellis, and R.J. Lawn. 1991. Towards the reliable prediction of time to flowering in six annual crops. I. The development of simple models for fluctuating field environments. Exp. Agr. 27:11-31.

U.S. Department of Agriculture. 2010. Floriculture crops 2009 summary. Agr. Stat. Board, Washington, DC.

U.S. Department of Energy. 1995. National solar radiation data base 1961-1990: Typical meteorological Year 2. Natl. Renewable Energy Lab., Golden, CO.

White, J.W. and I.J. Warrington. 1988. Temperature and light integral effects on growth and flowering of hybrid geraniums. J. Amer. Soc. Hort. Sci. 113:354-359. 